\title{
Tyrosine Kinase Inhibitors - Induced Cutaneous Leukocytoclastic Vasculitis
}

\section{Vasculite Leucocitoclástica Cutânea Induzida por Inibidores da Tirosina-Cinase}

Diogo Alpuim Costa ${ }^{1}$, Susana Baptista de Almeida² , Pedro Coelho Barata ${ }^{3}$, António Quintela ${ }^{1}$, Pedro Cabral ${ }^{4}$, Ana Afonso ${ }^{5}$, João Maia Silva ${ }^{6}$

KEYWORDS: Protein Kinase Inhibitors/adverse effects; Vasculitis, Leukocytoclastic, Cutaneous/chemically induced

PALAVRAS-CHAVE: Inibidores de Proteínas Cinases/efeitos adversos; Vasculite Leucocitoclástica Cutânea/induzida quimicamente

A 66-year-old patient with metastatic renal clear cell carcinoma, developed palpable purpura during systemic treatment with different tyrosine kinase inhibitors (TKI). One week after starting pazopanib, the patient presented a purpuric rash on both ankles. Initially, the condition was managed with temporary discontinuation and dose reduction of TKI. Biopsy proved leukocytoclastic vasculitis. No other organ was involved. The patient eventually switched to sunitinib due to recurrent toxidermia. Three weeks later, the reappearance of the same lesions was resolved with sunitinib withdrawal and prednisone $0.5 \mathrm{mg} / \mathrm{kg}$. Sunitinib was resumed with concomitant steroids at lower dose but discontinued due to tumour progression. After third-line nivolumab without significant side effects, cabozantinib was initiated with recurrence of the same vasculitic lesions. To the best of our knowledge, this is the first report of a significant cutaneous adverse reaction to three different TKIs in the same patient, illustrating a potential therapeutic class effect.

\footnotetext{
1. Haematology and Oncology Department, Instituto CUF de Oncologia (ICO), Lisboa, Portugal.

2. Oncology Department, Hospital Prof. Doutor Fernando Fonseca, Amadora, Portugal.

3. Experimental Therapeutics Fellow, Cleveland Clinic, Ohio, USA.

4. Radiology Department, Instituto CUF de Oncologia (ICO), Lisboa, Portugal.

5. Pathology Department, Instituto CUF de Oncologia (ICO), Lisboa, Portugal.

6. Dermatology Department, Instituto CUF de Oncologia (ICO), Lisboa, Portugal. 


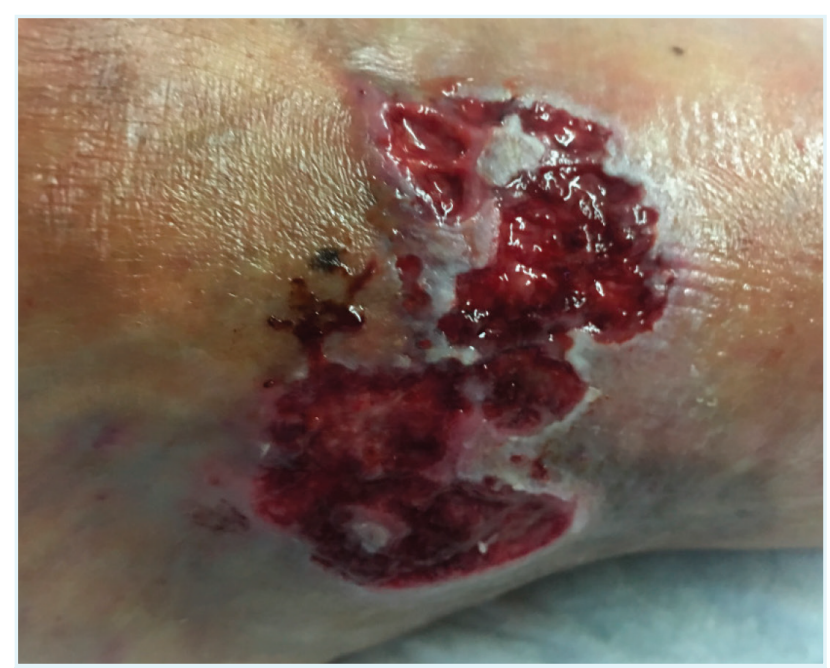

FIGURE 1

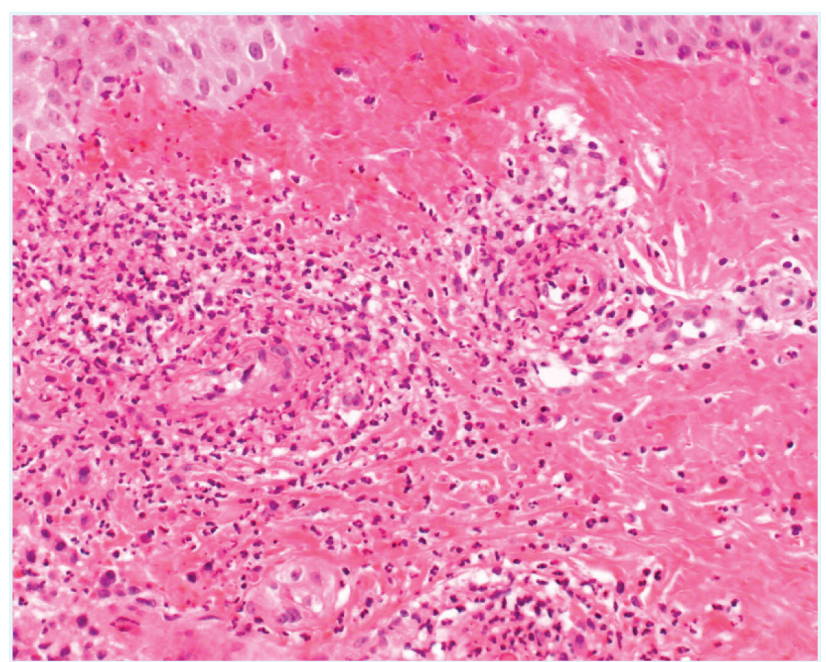

FIGURE 2

CONFLICTS OF INTEREST: The authors declare that they have no conflicts of interest.

FINANCIAL SUPPORT: This work has not received any contribution, grant or scholarship.

CONFIDENTIALITY OF DATA: The authors declare that they have followed the protocols of their work center on the publication of data from patients.

PROTECTION OF HUMAN AND ANIMAL SUBJECTS: The authors declare that the procedures followed were in accordance with the regulations of the relevant clinical research ethics committee and with those of the Code of Ethics of the World Medical Association (Declaration of Helsinki).

CONFLITOS DE INTERESSE: Os autores declaram não ter qualquer conflito de interesse na realização do presente trabalho.

FONTES DE FINANCIAMENTO: Não houve qualquer fonte de financiamento na realização do presente trabalho. CONFIDENCIALIDADE DOS DADOS: Os autores declaram ter seguido os protocolos da sua instituição acerca da publicação dos dados de doentes.

PROTEÇÃO DE PESSOAS E ANIMAIS: Os autores declaram que os procedimentos seguidos na elaboração do presente trabalho estão em conformidade com as normas das comissões de investigação clínica e de ética, bem como da declaração de Helsínquia e da Associação Médica Mundial. 